Report of Investigations 2011-3B

\title{
INTERPRETATIONS OF SEISMIC REFLECTION DATA AND STRUCTURAL CROSS SECTIONS FOR THE KAVIK RIVER MAP AREA, NORTHEASTERN BROOKS RANGE, ALASKA
}

by

Wesley K. Wallace

with contributions from mapping by

Marwan Wartes, Paul Decker, Paige Delaney,

Robert Gillis, Andrea Loveland, and Rocky Reifenstuhl

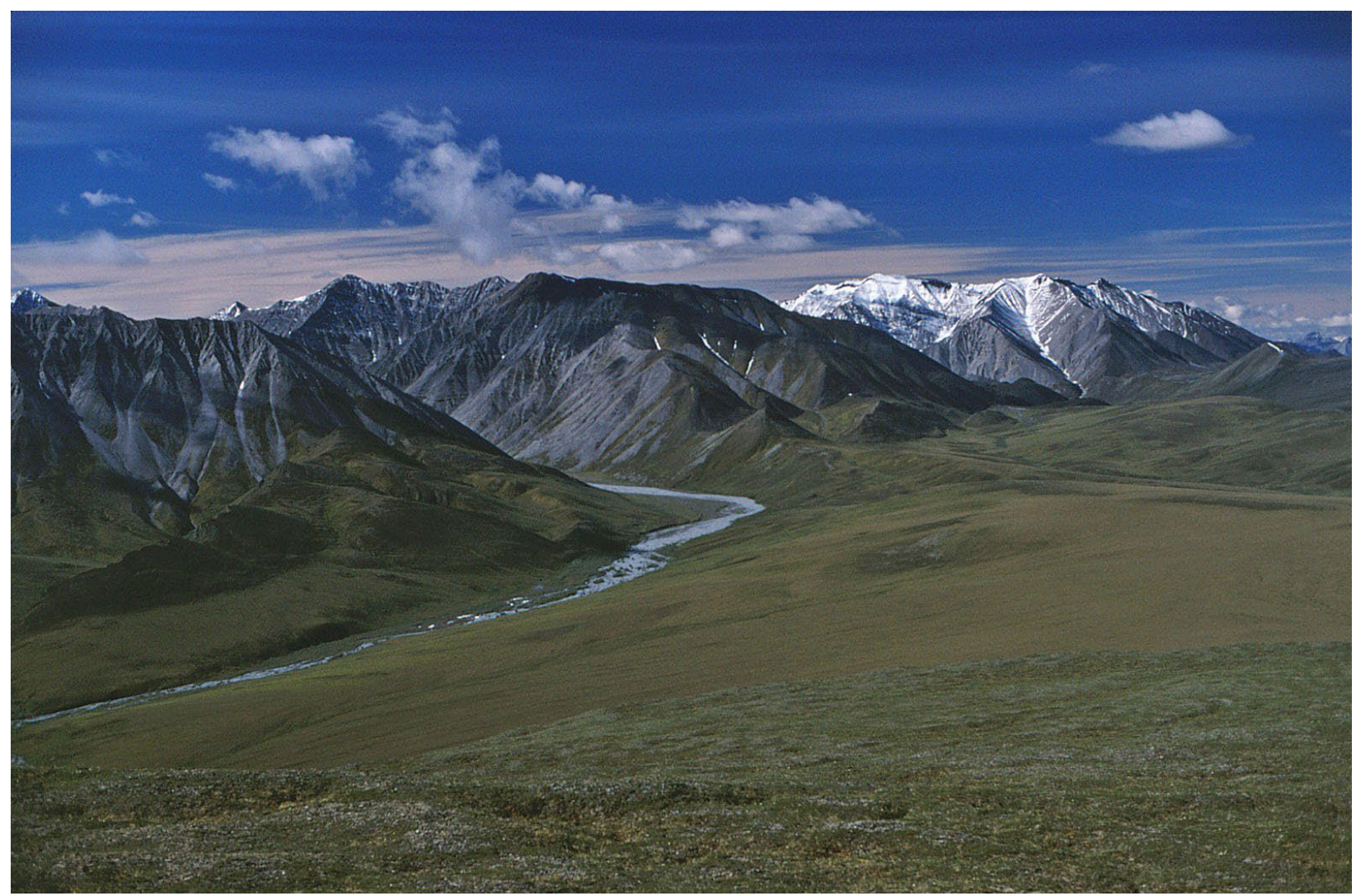

North limb of an east-northeast-trending anticline in the southeast corner of the Kavik River map area. The anticline is a detachment fold in the Lisburne and Sadlerochit Groups on the north limb of the basement-cored north Franklin Mountains anticlinorium. View is to the southwest. Photo by Wes Wallace.

\section{Published by}

STATE OF ALASKA

DEPARTMENT OF NATURAL RESOURCES 



\title{
Report of Investigations 2011-3B
}

\section{INTERPRETATIONS OF SEISMIC REFLECTION DATA AND STRUCTURAL CROSS SECTIONS FOR THE KAVIK RIVER MAP AREA, NORTHEASTERN BROOKS RANGE, ALASKA}

\author{
by \\ Wesley K. Wallace \\ with contributions from mapping by \\ Marwan Wartes, Paul Decker, Paige Delaney, \\ Robert Gillis, Andrea Loveland, and Rocky Reifenstuhl
}

2014

This DGGS Report of Investigations is a final report of scientific research. It has received technical review and may be cited as an agency publication. 


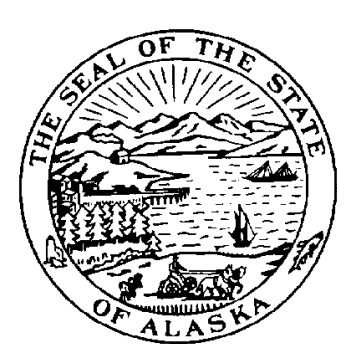

STATE OF ALASKA

Sean Parnell, Governor

DEPARTMENT OF NATURAL RESOURCES

Joe Balash, Commissioner

\section{DIVISION OF GEOLOGICAL \& GEOPHYSICAL SURVEYS \\ Steve Masterman, State Geologist and Director}

Publications produced by the Division of Geological \& Geophysical Surveys (DGGS) are available for free download from the DGGS website (www.dggs.alaska.gov). Publications on hard-copy or digital media can be examined or purchased in the Fairbanks office:

\section{Alaska Division of Geological \& Geophysical Surveys 3354 College Rd., Fairbanks, Alaska 99709-3707 \\ Phone: (907) 451-5020 Fax (907) 451-5050 \\ dggspubs@alaska.gov \\ www.dggs.alaska.gov}

Alaska State Library

State Office Building, 8th Floor 333 Willoughby Avenue

Juneau, Alaska 99811-0571

Elmer E. Rasmuson Library University of Alaska Fairbanks Fairbanks, Alaska 99775-1005
Alaska Resource Library \& Information Services (ARLIS)

3150 C Street, Suite 100

Anchorage, Alaska 99503

University of Alaska Anchorage Library 3211 Providence Drive Anchorage, Alaska 99508 


\section{CONTENTS}

Introduction 1

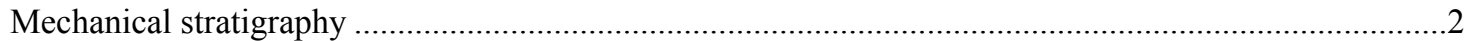

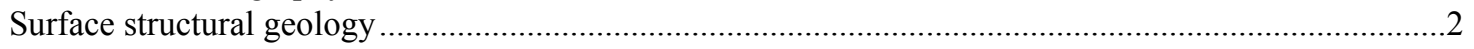

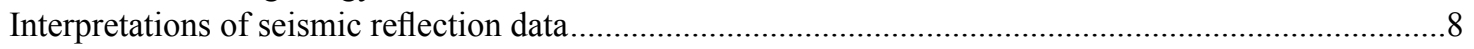

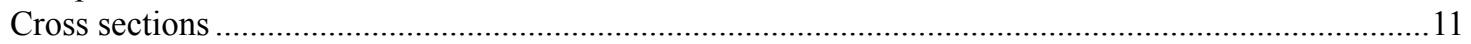

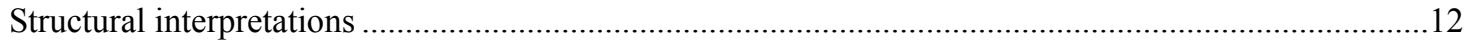

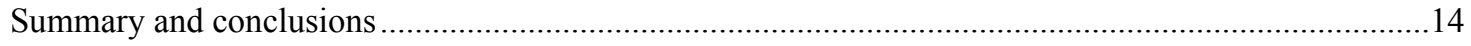

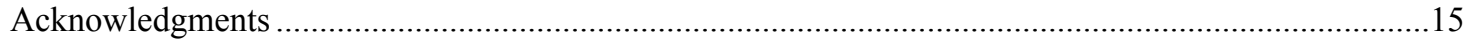



\section{FIGURES}

Figure 1. Terrane map of northern Alaska showing tectonic setting of Kavik River map area ............. 1

2. Generalized geologic map of Kavik River map area and vicinity ....................................2

3. Mechanical stratigraphy of the Kavik River map area .................................................. 3

4. Schematic diagram of changes in basement-involved structures from south to north parts of map area............................................................................................. 4

5. View from northwest of Kavik anticline, across Kavik River and view west of steep to overturned beds in Sagavanirktok Formation in forelimb of Kavik anticline..................... 5

6. View west of second-order detachment anticline on Fourth Range anticlinorium west of Canning River.

7. View east down plunge of second-order detachment anticline in Lisburne and Sadlerochit Groups along rangefront in south part of Kavik River map area .......................6

8. View east of folds in Kemik Sandstone cut by both fore- and back-thrusts ......................... 7

9. View west-southwest of gentle syncline in Kingak Shale through Juniper sandstone ............7

10. Views of west-northwest of gentle syncline and adjacent anticline west of Canning River and north of thrust-faulted folds in Kemik Sandstone on west bank of Canning River

11. View east of tight south-vergent folds in Hue Shale in structurally disrupted zone east of Kavik River .10

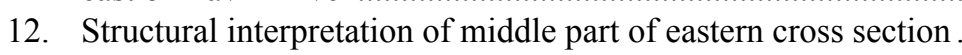

\section{APPENDIX}

Abbreviations for unit tops and other well markers on Kavik area seismic lines ........

\section{SHEETS}

(in envelope)

Interpretations of seismic reflection data and structural cross sections for the Kavik River map area, Alaska 



\section{INTERPRETATIONS OF SEISMIC REFLECTION DATA AND STRUCTURAL CROSS SECTIONS FOR THE KAVIK RIVER MAP AREA, NORTHEASTERN BROOKS RANGE, ALASKA}

by

Wesley K. Wallace

with contributions from mapping by

Marwan Wartes 2 , Paul Decker ${ }^{3}$, Paige Delaney ${ }^{2}$,

Robert Gillis ${ }^{2}$, Andrea Loveland ${ }^{2}$, and Rocky Reifenstuhl ${ }^{2}$

\section{INTRODUCTION}

The Kavik River map area (Wartes and others, 2011) extends from the northeastern Brooks Range to the northern limit of bedrock exposure in the foothills (figs. 1 and 2). This report presents structural observations and interpretations for the map area, illustrated by cross sections (sheets 1-3) that integrate surface observations with interpretations of seismic reflection data. The report relates the structures of the map area to adjacent structures in the northeastern Brooks Range to the east and south and in the foothills to the west. Loveland (2010) previously defined the regional basement structure in three dimensions by interpreting a grid of seismic reflection data that includes the map area. The objective of this report is to provide a more detailed analysis of the geometry and evolution of the structures of the map area.

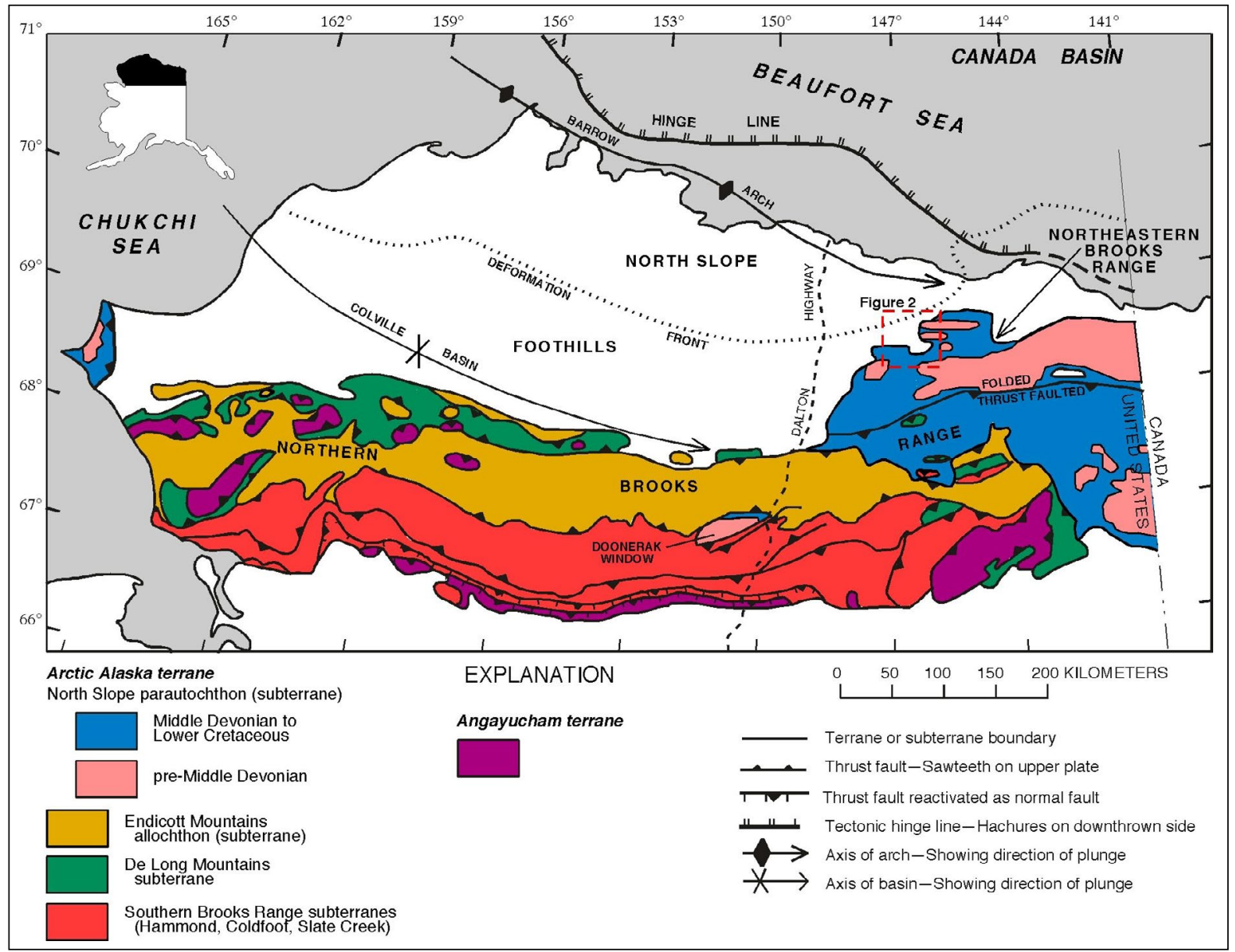

Figure 1. Terrane map of northern Alaska showing tectonic setting of Kavik River map area. Map area is along the northwestern edge of the northeastern Brooks Range and extends across the range front into its foothills. The northeastern Brooks Range is a younger structural salient relative to the east-trending main axis of the Brooks Range. Red dashed box shows area of figure 2. Modified from Moore others, 1994.

${ }^{1}$ Department of Geology \& Geophysics, University of Alaska, PO Box 757320, Fairbanks, AK 99775-5780; wallace@gi.alaska.edu

${ }^{2}$ Alaska Division of Geological \& Geophysical Surveys, 3354 College Road, Fairbanks, AK 99709-3707

${ }^{3}$ Alaska Division of Oil \& Gas, 550 W 7th Ave., Ste 800, Anchorage, AK 99501-3560 


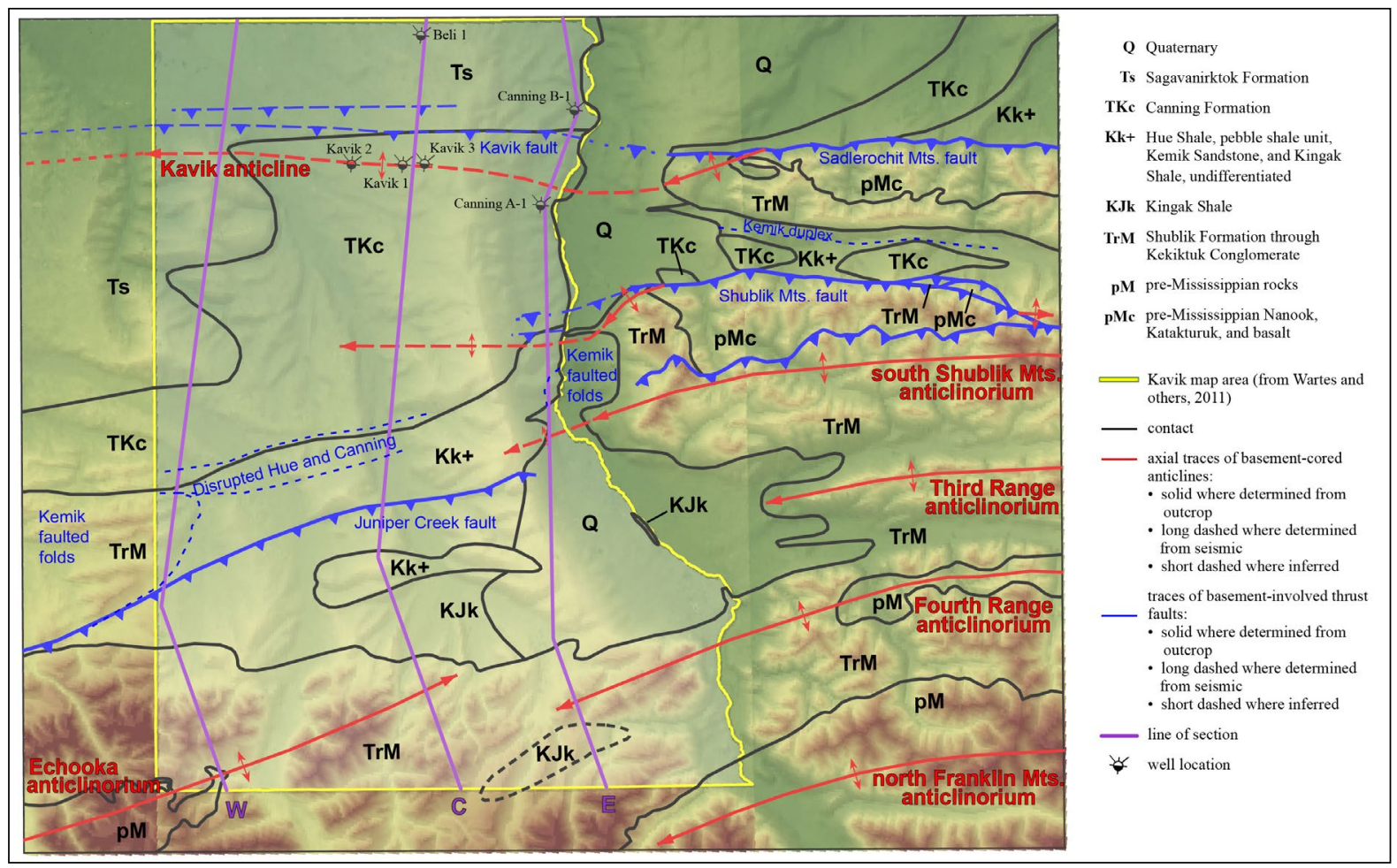

Figure 2. Generalized geologic map of Kavik River map area and vicinity. Rock units and major faults and folds are shown on a digital elevation model. Kavik River map area outlined in yellow, and cross section/seismic lines shown in purple. Modified from Bader and Bird (1986), Reifenstuhl others (2000), and Wartes others (2011).

\section{MECHANICAL STRATIGRAPHY}

The stratigraphy (Wartes and others, 2011) has a strong influence on the character of the structures in and around the map area (Wallace and Hanks, 1990; Wallace, 1993) (fig. 3). Throughout the section, mechanically competent units alternate with incompetent units that serve as structural detachment horizons. Variations in the relative and absolute thickness of the competent and incompetent units influence fold wavelength and the spacing and dip of thrust faults.

The lowest competent interval is mechanical basement that consists of polydeformed and weakly metamorphosed sedimentary and subordinate volcanic rocks. This basement is generally referred to as pre-Mississippian because Mississippian Kekiktuk Conglomerate overlies it in angular unconformity through most of the region, but it was probably deposited and deformed before Middle Devonian time (Anderson and others, 1994; Moore and others, 1994). The basement and a thin veneer of Kekiktuk are separated by an important regional detachment in the Mississippian Kayak Shale from the overlying thick and competent carbonates of the Mississippian and Pennsylvanian Lisburne Group. Siliciclastic rocks of the Permian and Triassic Sadlerochit Group and argillaceous clastic and carbonate rocks of the Triassic Shublik Formation overlie the
Lisburne Group. The Sadlerochit and Shublik generally deform with the underlying Lisburne, with minor detachment in finer-grained intervals in these units. The thick Jurassic and Lower Cretaceous Kingak Shale forms another major regional detachment interval. The laterally variable Kemik Sandstone forms a relatively thin but important competent unit between Kingak Shale and the overlying pebble shale unit. The pebble shale unit, the Hue Shale, and the mudstone and thin-bedded, fine-grained sandstone of the Upper Cretaceous and Paleocene Canning Formation form a very thick incompetent interval. Sandstone and conglomerate of the Paleocene to Miocene Sagavanirktok Formation form competent intervals that intertongue with the upper part of the Canning Formation.

\section{SURFACE STRUCTURAL GEOLOGY}

The Kavik River map area is near the northern edge of north-vergent contractional structures related to formation of the northeastern Brooks Range (fig. 1). The map area extends northward from the northeastern Brooks Range across the range front into the foothills (fig. 2) and so provides exposures of stratigraphy and structure in rocks from pre-Middle Devonian basement through Cenozoic foreland basin deposits (fig. 3). Structural relief decreases northward, with a corresponding 


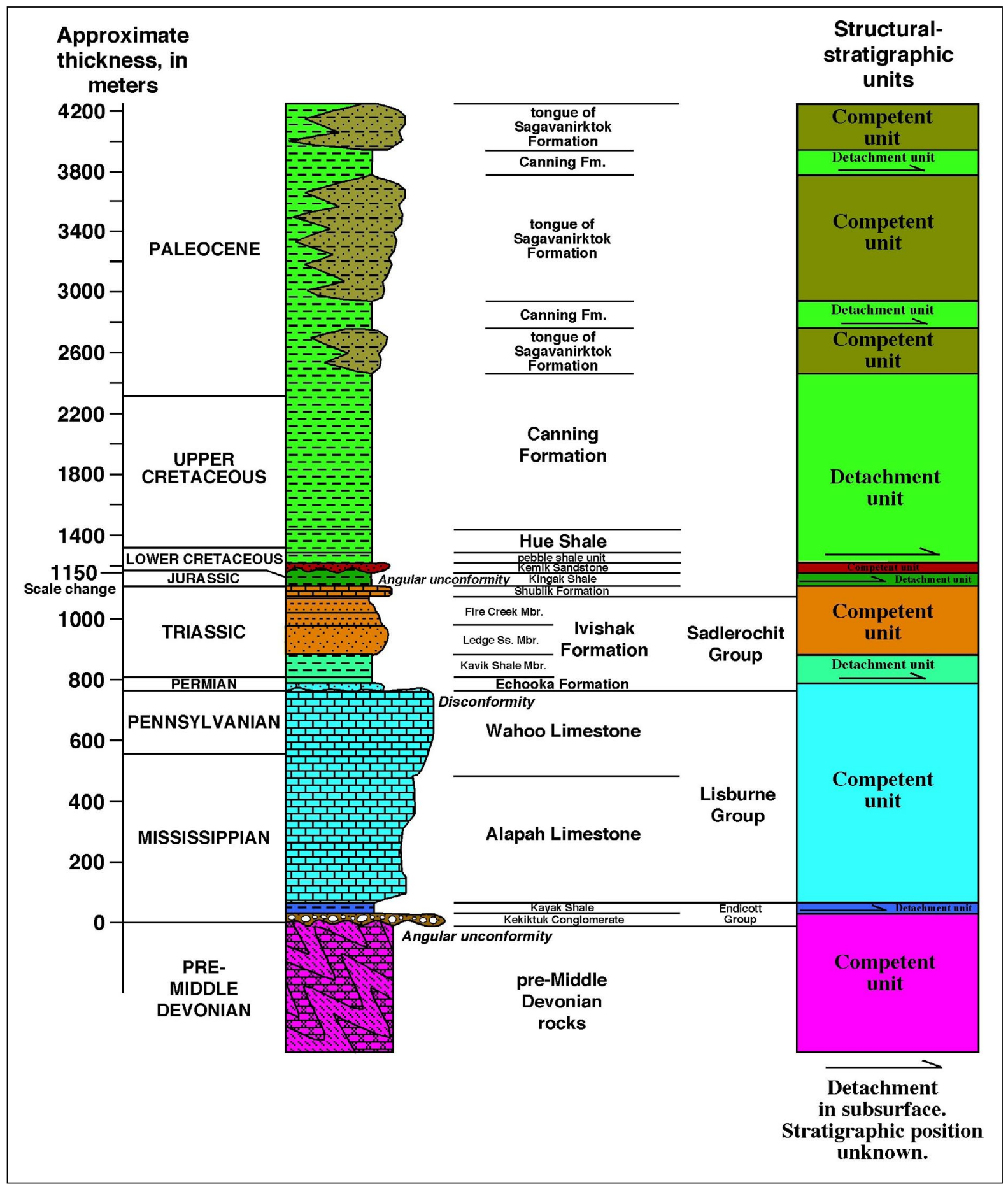

Figure 3. Mechanical stratigraphy of the Kavik River map area. Left column shows lithostratigraphy and right column shows major competent and incompetent (detachment) units. The Juniper sandstone (Wartes others, 2011) is not shown. This local unit is present in a belt between the range front and the Juniper Creek fault. It occupies the approximate position of the Hue Shale, but its complete age range is unknown. Note scale change at Lower Cretaceous unconformity, between Kingak Shale and Kemik Sandstone. Below Lower Cretaceous unconformity modified from Wallace others (1997). 
northward decrease in both surface elevation and depth of erosion. Progressively younger units are exposed northward, and a northward change in structural style reflects both position within the mechanical stratigraphy and decreasing distance from the deformation front. The structures exposed at the surface are described here from structurally and stratigraphically lowest to highest.

The structure exposed in the map area is similar to that observed along trend in the mountains east of the Canning River (fig. 2) (Reiser and others, 1971; Bader and Bird, 1986; Kelley and Foland, 1987; Robinson and others, 1989; Wallace and Hanks, 1990; Wallace, 1993). The important difference is that structures plunge abruptly westward across the Canning River, allowing preservation in the map area of higher levels of stratigraphy and structure that are mostly eroded in the mountains to the east.

The largest and structurally lowest structures are anticlines in the pre-Middle Devonian basement and the unconformably overlying Kekiktuk Conglomerate (fig. 3 and sheets 1-3). These folds have wavelengths of $\sim 5-15 \mathrm{~km}$ and height between anticline and syncline of $\sim 0.5-5 \mathrm{~km}$, and their north limbs are typically shorter and steeper than their south limbs. These structures have been interpreted in the northeastern Brooks Range and the coastal plain of the Arctic National Wildlife Refuge to be fault-bend folds that formed beneath a detachment in the Kayak Shale (fig. 4) (Wallace and Hanks, 1990; Wallace, 1993; Potter and others, 1999, 2004). The eastnortheast-plunging end of the Echooka anticlinorium is in the southwest corner of the map area and is the only one of these structures that exposes basement and Kekiktuk in the map area (fig. 2). To the east, across a structural low marked by exposures of the Shublik and
Kingak Formations, a structural high in the Lisburne and Sadlerochit Groups marks the west-southwest-plunging end of the Fourth Range anticlinorium (figs. 2 and 3). The north limb of the larger north Franklin Mountains anticlinorium lies to the south, in the southeast corner of the map area. Underlying basement structure is less obviously reflected in Kingak and younger units north of the mountain front, except for the conspicuous Kavik anticline and thrust fault in the northern part of the map area (fig. 2).

In the northeastern Brooks Range, basement faults typically do not cut upsection across the Kayak Shale. The range-front faults in the Sadlerochit and Shublik mountains are notable exceptions (fig. 2). The east strike of these faults is interpreted to reflect reactivation of pre-Middle Devonian faults, and the fact that they cut upsection from basement is attributed to the unusually thick and competent basalt and carbonate of the local basement stratigraphy (Wallace and Hanks, 1990; Wallace, 1993). The Kavik fault in the northern part of the map area is defined well in surface exposures and appears to be a westward continuation of the Sadlerochit Mountains fault (fig. 2 and sheets 1-3). This fault cuts upsection into the Sagavanirktok Formation, which includes the youngest rocks exposed within the map area. The fault is bounded to the south by an anticline in the Sagavanirktok Formation that reflects basement structure and is wide and gentle except for a narrow north limb that is steep and locally overturned (fig. 5 and sheet 3 ).

South of the mountain front, broad highs and lows defined by the Kekiktuk through Shublik Formations presumably mark first-order folds in underlying basement (figs. 2 and 3 and sheets 1-3). Second-order and higher-order parasitic folds in Lisburne through Shublik

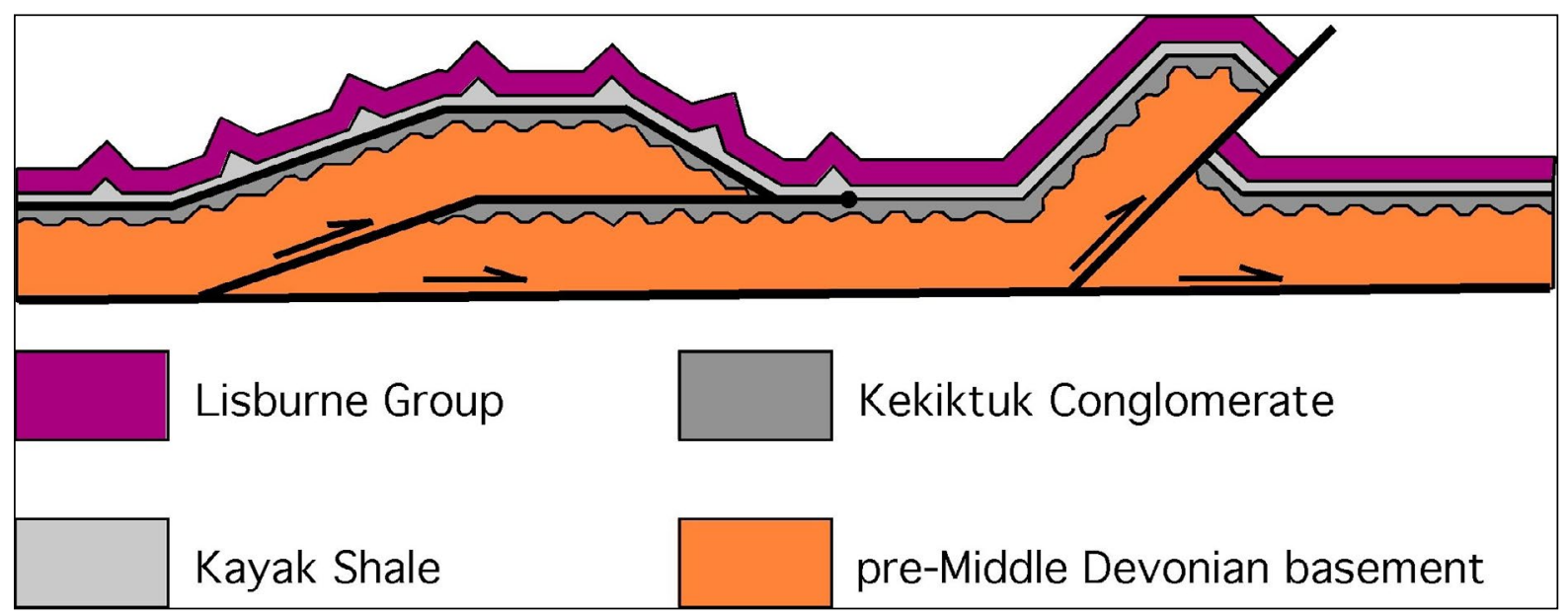

Figure 4. Schematic diagram of changes in basement-involved structures from south to north parts of map area. Left: To south, detachment in Kayak Shale separates fault-bend folds in basement (plus thin veneer of Kekiktuk) below from detachment folds in Lisburne Group above. Right: To north, steep faults cut up-section from basement, with no detachment in Kayak Shale. Modified from Wallace and Hanks (1990) and Wallace others (1997). 

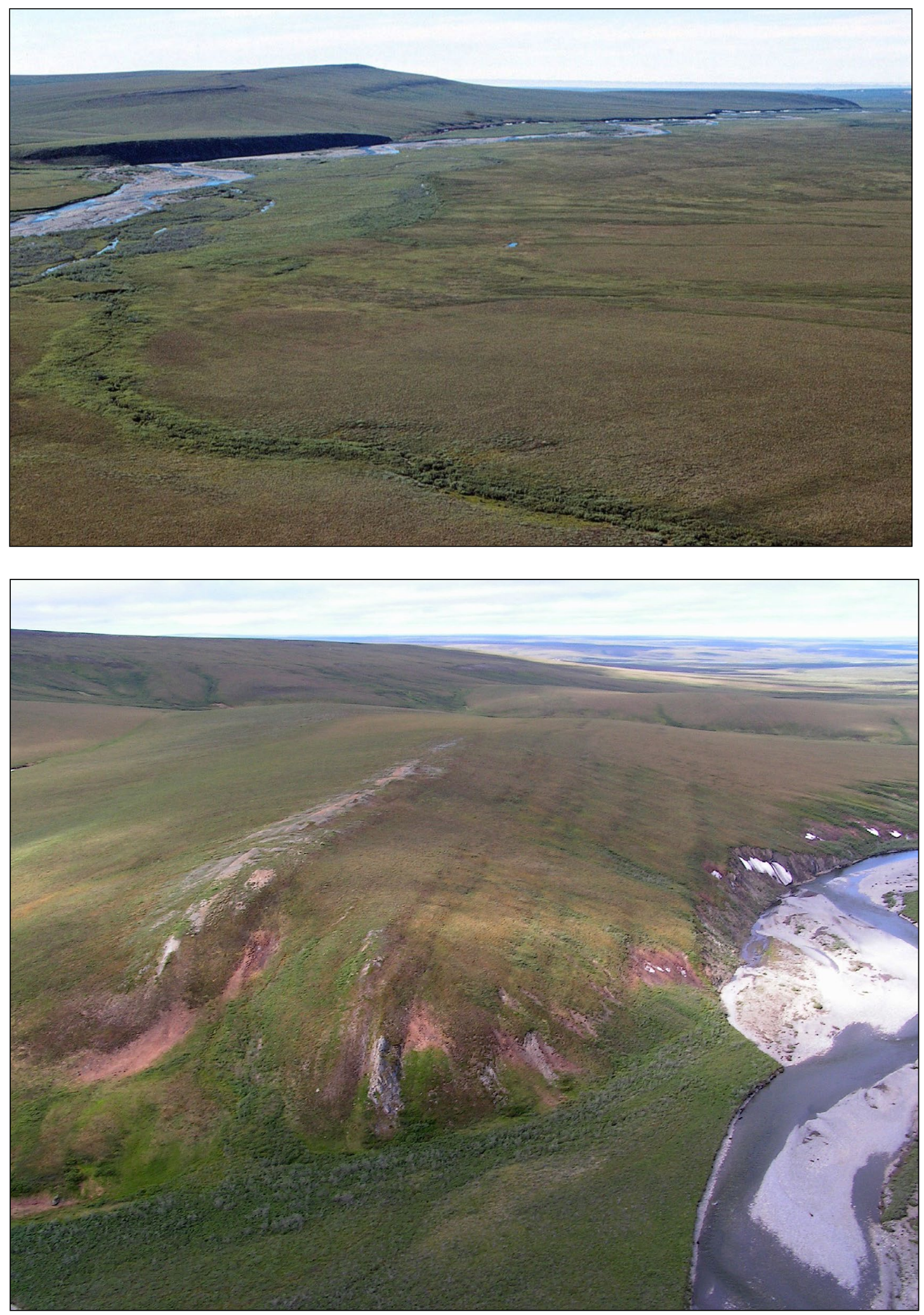

Figure 5. (A) View from northwest of Kavik anticline, across Kavik River. Beds in Sagavanirktok Formation dip gently south in backlimb to left, steep to overturned beds in forelimb to right. River bluff in shadow is in Canning Formation. (B) View west of steep to overturned beds in Sagavanirktok Formation in forelimb of Kavik anticline, gently dipping beds in backlimb on ridgeline to left. 


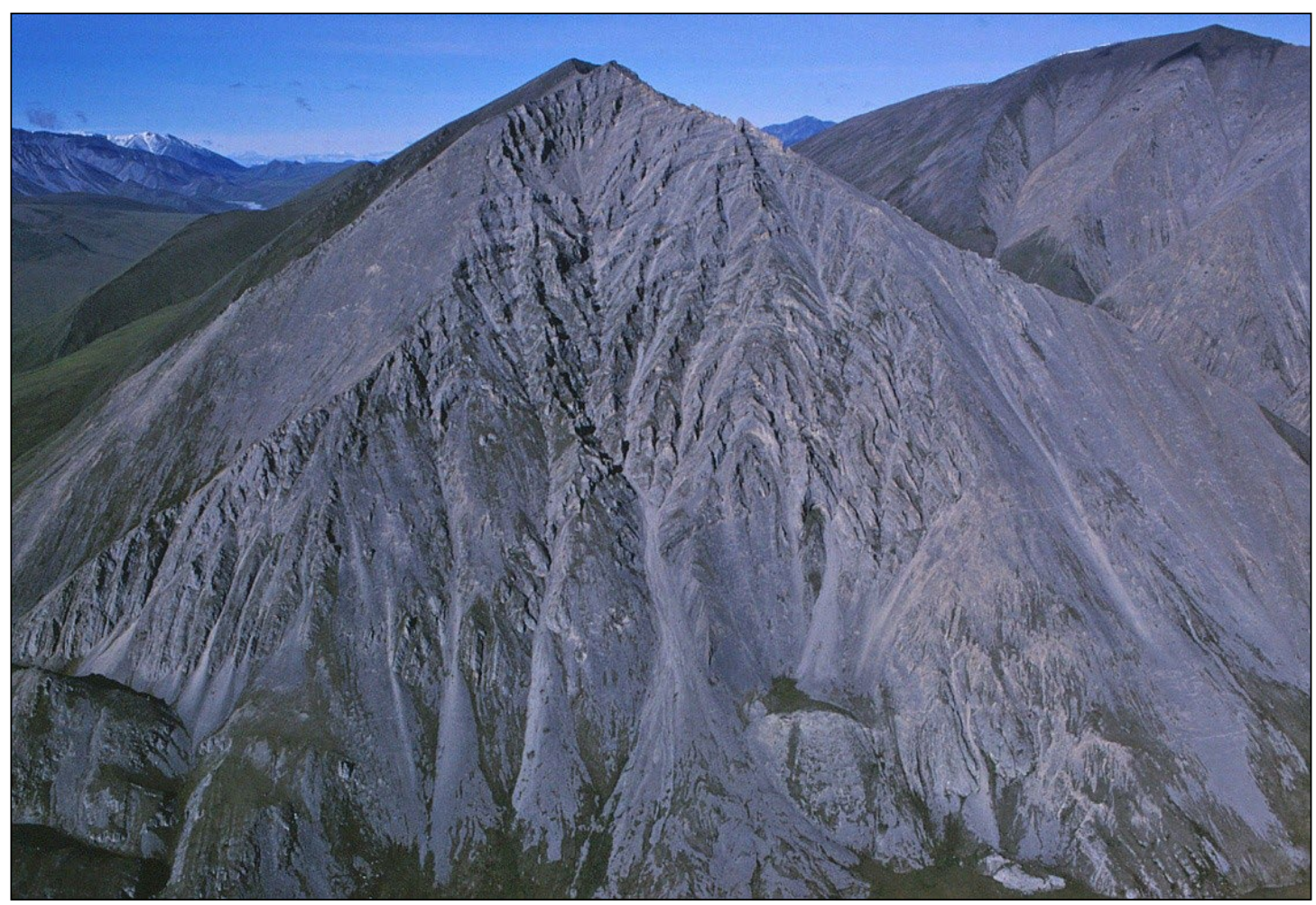

Figure 6. View west of second-order detachment anticline on Fourth Range anticlinorium west of Canning River. A second anticline is in background to right. Brown clastic rocks of Sadlerochit Group overlie gray Lisburne Group carbonates in both anticlines.

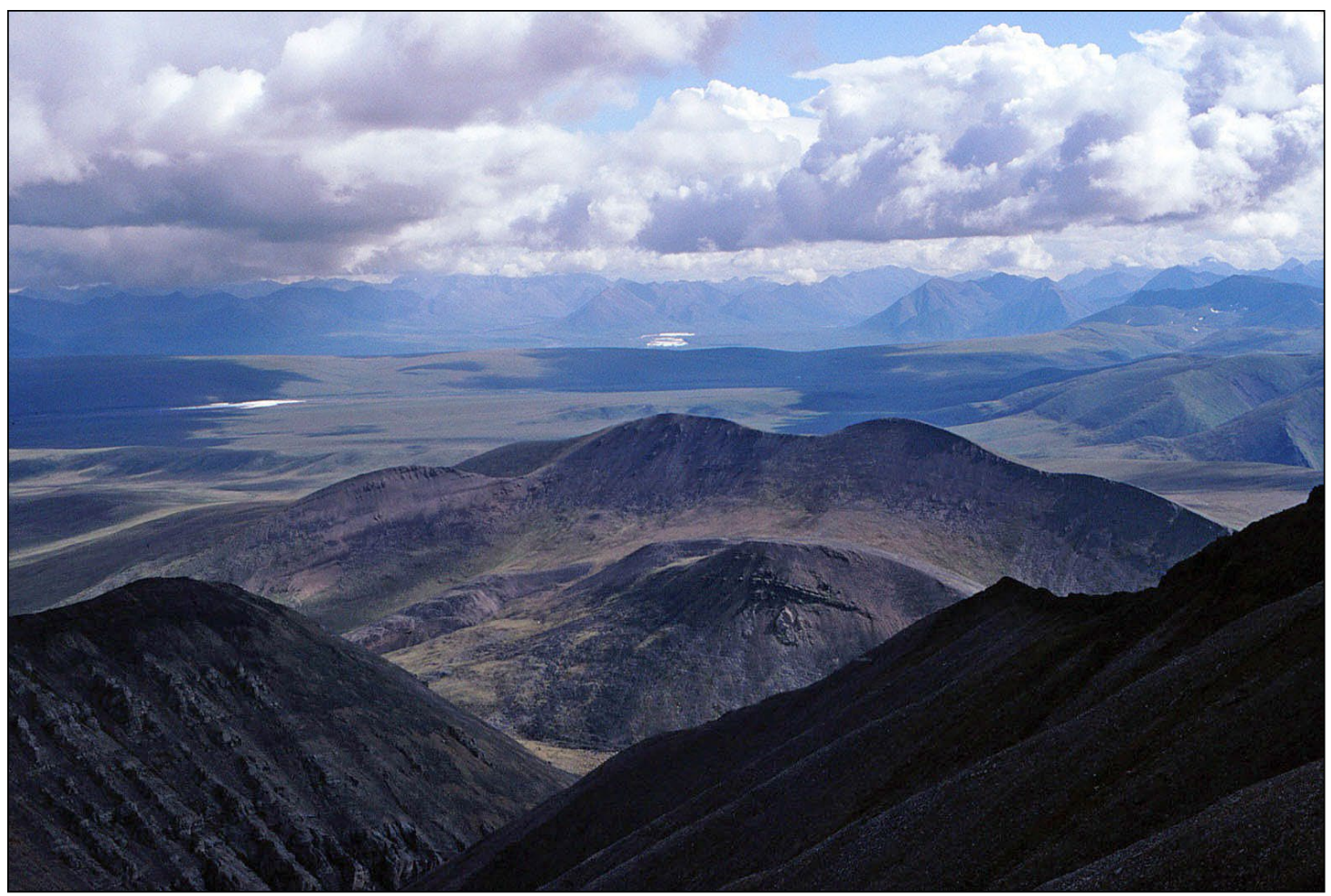

Figure 7. View east down plunge of second-order detachment anticline in Lisburne and Sadlerochit Groups along rangefront in south part of Kavik River map area. Prominent tundra-covered shelf marks Kavik Shale. En echelon arrangement of similar anticlines defines rangefront in right background. Fourth Range is east of Canning River to right of aufeis in far background. 


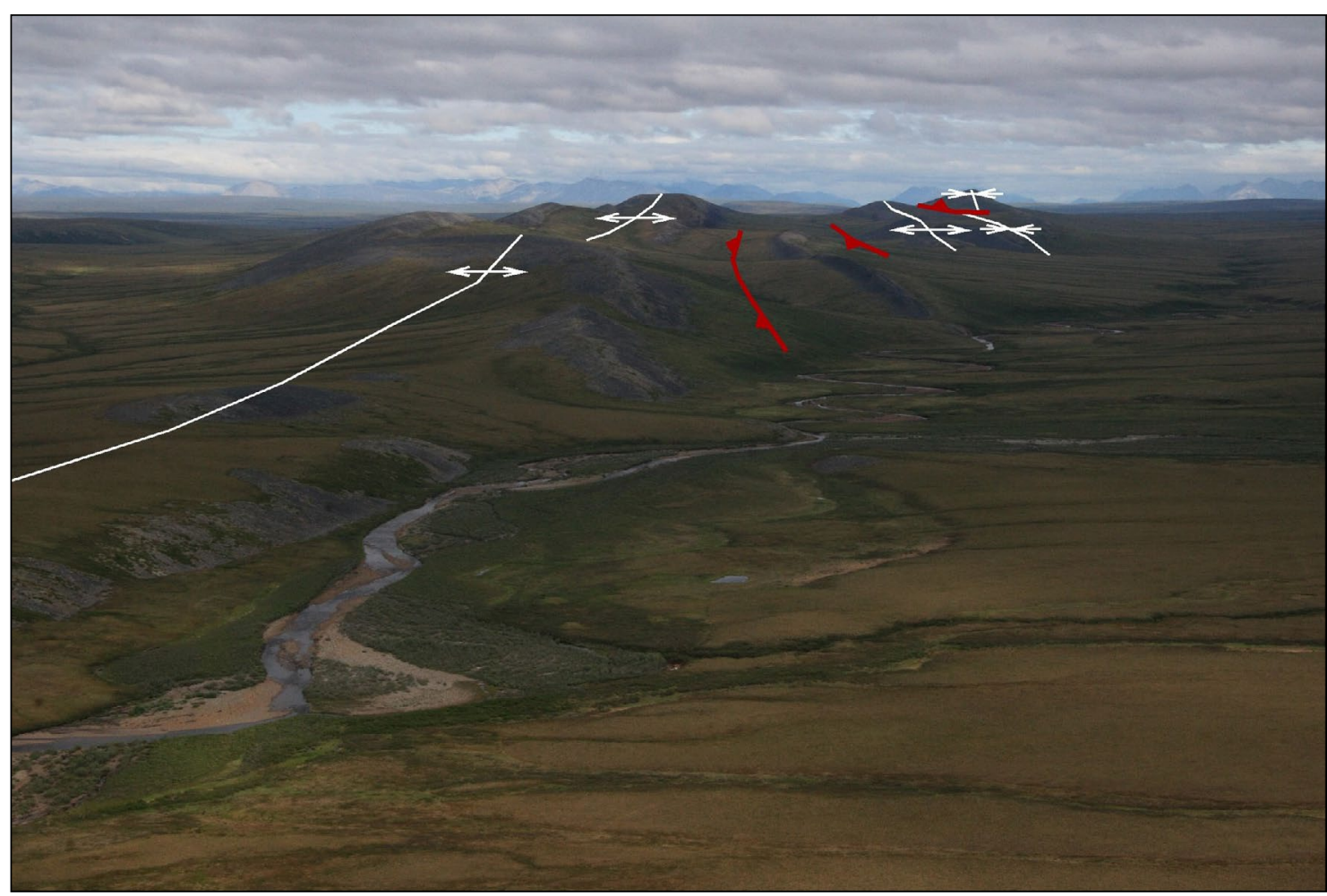

Figure 8. View east offolds in Kemik Sandstone cut by both fore-and back-thrusts. Kemik Creek in foreground. Ridges extend into west edge of Kavik River map area. Mountains east of Canning River in background, from left to right, Sadlerochit Mountains, Shublik Mountains, Third Range, and Fourth Range.

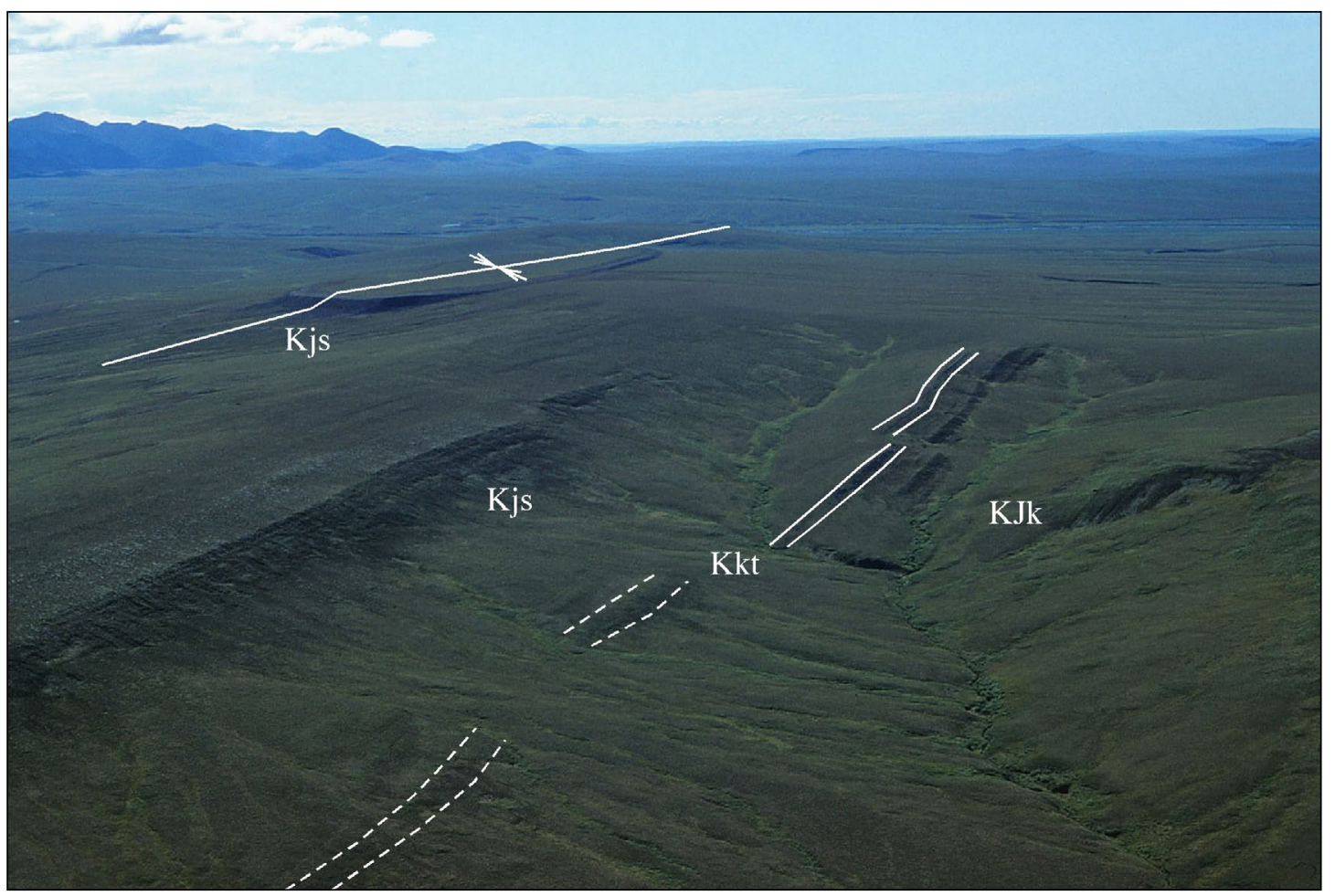

Figure 9. View west-southwest of gentle syncline in Kingak Shale through Juniper sandstone. KJk = Kingak Shale; Kkt = Kemik Sandstone thin facies; Kjs = Juniper sandstone. Rangefront in background to left; gentle ridges in background to right are imbricated Kemik Sandstone just west of Kavik River map area. 
are detachment folds that formed above a main detachment in the Kayak Shale and subordinate detachments in the lower Echooka Formation and the Kavik Shale (figs. 3, 6, and 7). The second-order folds are generally upright and symmetrical and have wavelengths of $\sim 1.25-3.0 \mathrm{~km}$, heights between anticline and syncline of $\sim 0.25-0.5 \mathrm{~km}$, and interlimb angles of $\sim 150-110^{\circ}$. Parasitic folds in the Lisburne Group through Shublik Formation have wavelengths of $\sim 0.25-0.75 \mathrm{~km}$ and limb dips of $\sim 20-70^{\circ}$. As in the northeastern Brooks Range, folds in Lisburne to Shublik are rarely cut by thrust faults (Wallace and Hanks, 1990; Wallace, 1993), and only one such fault is present in the southwest corner of the map area (sheet 3). Lisburne and Sadlerochit display variably developed axial-planar solution cleavage and slaty cleavage. Cleavage generally increases southward and in the cores of tighter folds, and is most common in the more argillaceous carbonates and in shale and siltstone.

Kingak Shale (fig. 3 ) is poorly exposed in a belt just north of the range front (fig. 2). This thick shale unit acts as a detachment that separates distinctly different structural styles above and below (sheets 1-3). It displays folds with wavelengths of $\sim 0.25-1.0 \mathrm{~km}$ and limb dips of $\sim 25-85^{\circ}$. The unit probably is significantly structurally thickened, as reflected by the more than $1,830 \mathrm{~m}$ $(6,000 \mathrm{ft})$ of Kingak penetrated in the Kemik 2 well, $\sim 9$ $\mathrm{km}$ west of the map area.

Kemik Sandstone is a competent and erosionally resistant unit between the Kingak Shale and the pebble shale unit (fig. 3). It is relatively well exposed in a belt across the central part of the map area (fig. 2), and varies in its structural character. East-northeast-plunging folds with wavelengths of $\sim 0.5-2.5 \mathrm{~km}$ and interlimb angles of $135-100^{\circ}$ are exposed at the western edge of the map area (fig. 8 and sheet 3 ). These mark the eastern end of a more extensive exposure of Kemik folds that are commonly breached by thrust faults that dip both north and south (Reifenstuhl and others, 2000). Several south-dipping thrust faults are inferred to cut the Kemik folds in the map area.

Wide ( 1-4 km) and gentle folds in the Kemik Sandstone, the pebble shale unit, and the Juniper sandstone to the south are exposed in the central and eastern part of the map area (fig. 9 and sheets 1 and 2). Abrupt differences in thickness and character of the stratigraphic units between adjacent folds suggest that some of these folds may be cut by thrust faults. The most prominent and laterally extensive example of these is the Juniper Creek fault (fig. 2). This fault defines the northern boundary of a stratigraphic section that differs from that to the north in that Kemik is very thin, Hue Shale is absent, and the Juniper sandstone is present.

A different structural style is exposed in Kemik Sandstone along the Canning River, at the eastern edge of the map area and just north of the belt of gentle folds (figs. 2 and 10 and sheet 1). Folds with wavelengths of $\sim 0.25-0.75 \mathrm{~km}$, limb dips of $30-80^{\circ}$, and interlimb angles of $135-100^{\circ}$ are cut by south-dipping thrust faults that apparently are nearly parallel with bedding up-dip in the footwall.

The faulted folds in Kemik at the eastern and western edges of the map area differ from imbricated Kemik reported along trend to the east-northeast in Ignek Valley and the Sadlerochit Mountains (Meigs, 1989; Wallace and Hanks, 1990; Rogers, 1992; Wallace, 1993). There, Kemik forms duplexes that display significant overlap on thrust faults at a low angle to bedding and with relatively little folding. In contrast, the Kemik folds in the map area are cut at a high angle to bedding by relativelysmall-displacement faults. These folds probably formed between the detachments in the Kingak and pebble shales (fig. 3) and were broken by thrust faults as they tightened.

A 1-2-km-wide zone of intense structural disruption in the Hue Shale and Canning Formation lies along trend to the west-southwest of the short-wavelength faulted folds in the Kemik along the Canning River (fig. 2). This zone is characterized by folds with wavelengths of $\sim 100-400 \mathrm{~m}$ and interlimb angles of $90-15^{\circ}$. These folds are commonly overturned and cut by multiple thrust faults (fig. 11). The zone is generally north vergent, but is distinctly south vergent along the Kavik River. The zone displays complex mixing of Hue and Canning on multiple steep faults along Juniper Creek. Exposures of Hue Shale are limited mainly to this disrupted zone, so it is not known whether such strong structural disruption is typical in Hue Shale elsewhere in the area.

North of the disrupted zone, the Canning and Sagavanirktok Formations display gentle folds with $2-5 \mathrm{~km}$ wavelength (fig. 5A and sheets 1-3). The Canning Formation also displays local open to closed parasitic folds with 200-1,000 m wavelength, but these are absent in the Sagavanirktok Formation, which is more competent because of its thicker bedding and larger grain size. The Kavik fault is marked at the surface by local steep to overturned bedding (fig. 5B). Other than the Kavik fault, no map-scale faults were observed to cut Canning or Sagavanirktok at the surface.

Throughout the map area, folds trend and thrust faults strike east-northeast, reflecting a north-northwest structural transport direction. The east-striking Kavik thrust fault and the parallel anticline to the south are the notable exceptions. The lack of east-striking structures south of the Kavik fault and anticline contrasts with the east-striking basement-involved structures east of the Canning River, from the Fourth Range north to the Sadlerochit Mountains (fig. 2) (Wallace and Hanks, 1990; Wallace, 1993). 


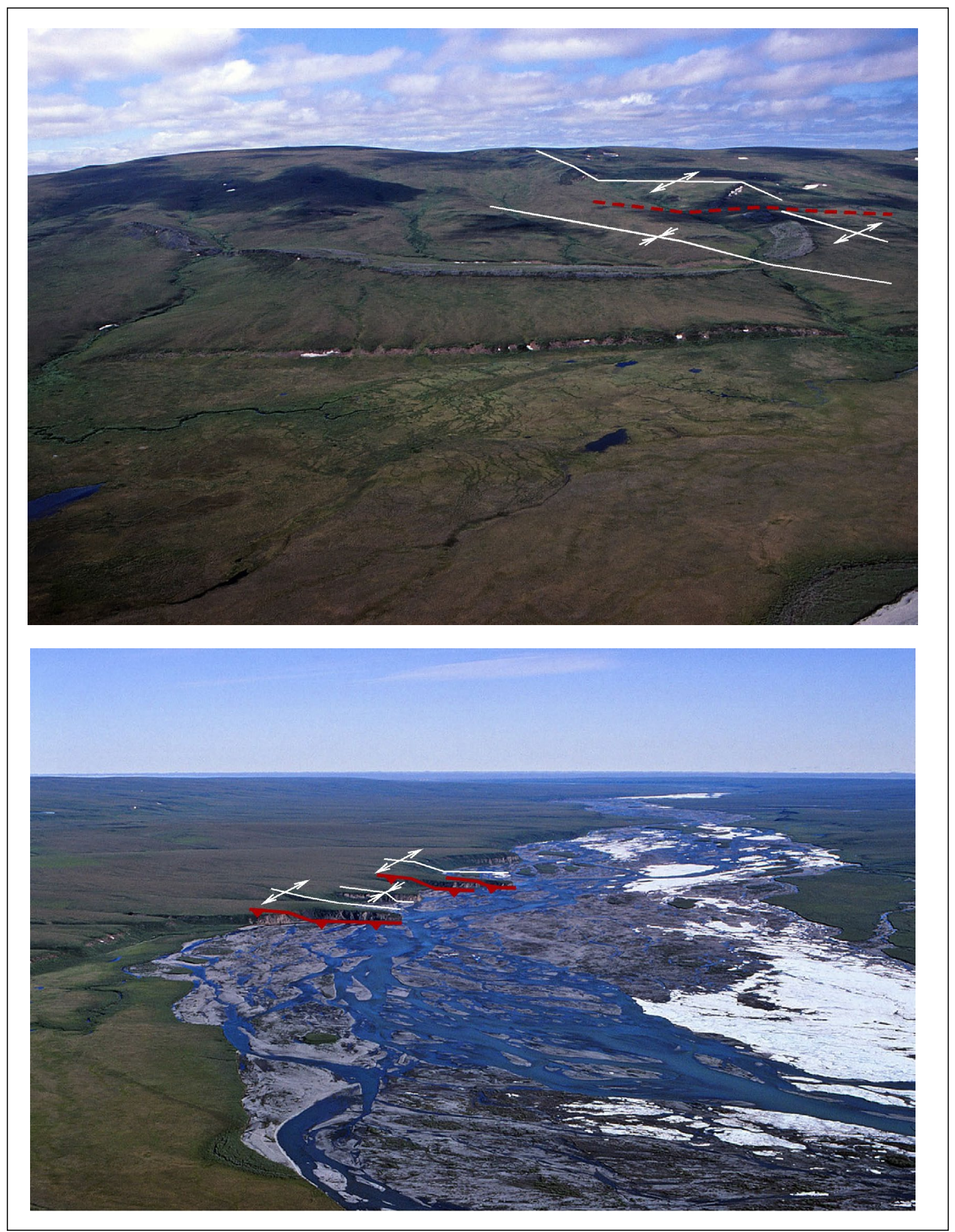

Figure 10. (A) View west-northwest of gentle syncline and adjacent anticline west of Canning River. (B) View north of thrust-faulted folds in Kemik Sandstone on west bank of Canning River. These outcrops are immediately north of folds in A. 


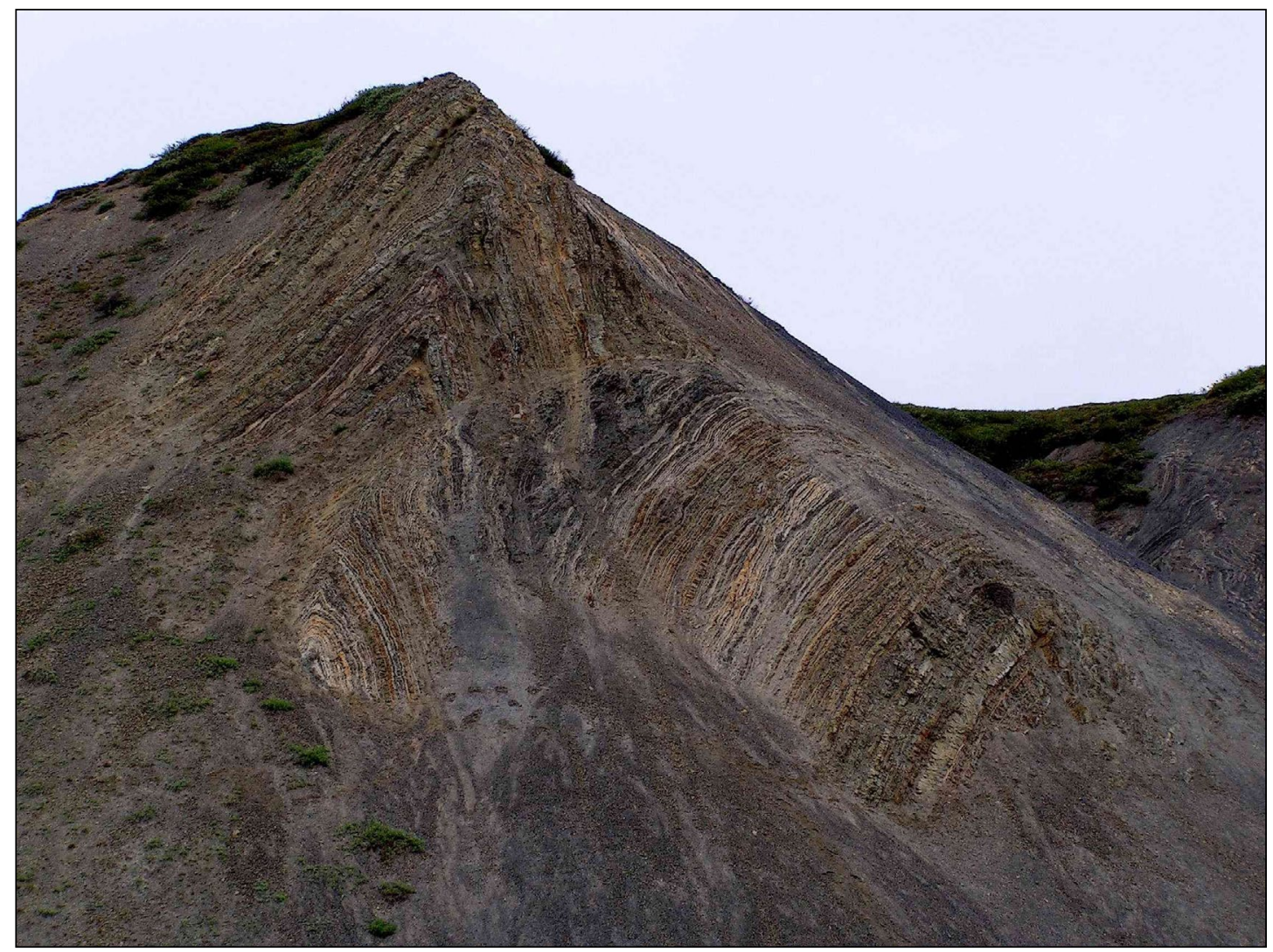

Figure 11. View east of tight south-vergent folds in Hue Shale in structurally disrupted zone east of Kavik River.

\section{INTERPRETATIONS OF SEISMIC REFLECTION DATA}

Seismic reflection data that were collected in 1980 and 1981 now are available publicly on a widely spaced grid that includes the northern and central part of the map area. I interpreted three lines oriented at a high angle to the strike of structures to provide insight into the subsurface structure. These are identified according to their location as follows:

- East line: EP 81-27

- Central line: ARCO 80-06

-West line: EP 81-28

Data quality in these lines varies. Data quality deteriorates southward to the point that interpretation is speculative to impossible approaching the range front. Little interpretation is possible in basement because of the lack of coherent reflectors. The data are quite noisy down to $\sim 0.05$ seconds, so shallow reflectors are difficult to trace and are speculative in places.

I interpreted only enough seismically distinctive reflectors to define the structure without cluttering the interpretation or forcing interpretation of indistinct reflectors of uncertain identity. I correlated stratigraphic units with reflectors using logs from four wells (Canning River A-1 and B-1, Kavik 1, and Beli 1) along the east and central lines. I chose three horizons to interpret because they are relatively distinctive and continuous reflectors that serve well to define the structure: The top of pre-Middle Devonian basement, the top of Shublik, and the Lower Cretaceous unconformity ( $\mathrm{LCu}$ ), which underlies the Kemik. Above $\mathrm{LCu}$, some reflectors can be correlated to specific stratigraphic horizons north of the Kavik fault, but none can be traced reliably from points of well control south of the fault. In areas where reflectors could not be correlated with stratigraphy, unidentified reflectors were traced as far as possible to define structural form lines, mainly above LCu but locally in basement. The seismic interpretations were converted to depth (discussed below) so they could be incorporated into the cross sections with correct dips and thicknesses.

The seismic lines (sheets 1-3) show that depth to basement increases progressively to the north. The top of basement is offset by thrust faults that typically dip moderately to steeply, mainly to the south, and generally have hangingwall anticlines. The basement faults typically are steepest $\left(50-70^{\circ}\right)$ where they cut through Lisburne to 
Shublik, but commonly are less steep $\left(25-40^{\circ}\right)$ below or above this interval. The faults decrease in number and are more widely spaced westward. The faults usually cannot be identified in basement because of the lack of coherent reflectors, but they are well defined where they offset the basement-cover contact. Most of these faults cut upsection to detachments at different stratigraphic levels above basement, most commonly in Kingak Shale, and some cut to the surface. North-dipping backthrusts locally cut upsection from basement or define wedges where they branch from one of the south-dipping basement faults at a point near the basement-cover contact. The backthrusts generally have relatively small displacement.

The Kavik fault is the basement-involved thrust that is best defined in surface geology and most easily correlated between seismic lines (fig. 2 and sheets $1-3$ ). The fault dips steeply $\left(50-70^{\circ}\right)$ to the south and cuts upsection to Sagavanirktok at the surface. It appears to be a single fault in the eastern line, but is interpreted to have two branches westward because the apparent location of the fault on the seismic data is north of the location of the fault as determined by locally steep to overturned beds exposed in the Sagavanirktok. The Kavik fault apparently correlates with the Sadlerochit Mountains fault (fig. 2), which lies directly along strike to the east and cuts upsection at least to the Canning Formation, the youngest unit exposed along the mountain front.

The other basement-involved thrusts interpreted from the seismic data are difficult to correlate to faults mapped at the surface or between seismic lines. A fault that cuts to the surface in the eastern line appears to correlate with the Shublik Mountains fault (fig. 2), but cannot be identified in the lines farther west. The Juniper Creek fault in the eastern line appears to be another basement-involved thrust that cuts to the surface (sheet 1).

The hangingwall anticlines of the basement-involved thrusts are typically wide, gentle, and rounded. The Kavik wells and the Canning A-1 well were located on the crest of the Kavik anticline. Both the Canning B-1 and the Beli wells were located north of the Kavik fault. The Canning B-1 well is on the crest of the hangingwall anticline south of a basement forethrust, but the Beli well was on the hangingwall anticline north of a basement backthrust.

The first-order basement-cored folds are visible upsection at least to the pebble shale unit (fig. 3). Little or no detachment folding is visible in the Lisburne above the Kayak Shale, and only minor and local parasitic folds are visible in Sadlerochit and Shublik.

The LCu reflector clearly defines complex imbrication on all three of the lines (sheets 1-3). This appears to represent imbrication of Kemik between detachments in Kingak and the pebble shale unit (fig. 3). The faults that duplicate Kemik are spaced $\sim 0.25-0.75 \mathrm{~km}$ apart and mostly dip gently to the south, although a few backthrusts are present in the southern part of the imbricated zone on the central line (sheet 2). The imbrication spans a zone at least $11.5-12.5 \mathrm{~km}$ across strike. The northern edge of the zone lies 1-2 km south of the Kavik anticline in the central and western lines (sheets 2-3). However, in the eastern line (sheet 1), it is folded over the top of the Kavik anticline, indicating that imbrication predated the basement-involved faulting that formed the anticline. The zone is also locally breached by other basement-involved thrusts.

In the eastern line (sheet 1), a strong reflector interpreted to be the $\mathrm{LCu}$ is present in two areas of coherent data south of the Shublik Mountains fault. The northern of these appears to define an upward continuation of the hangingwall anticline of the Shublik Mountains fault and shows no imbrication. The crest of this anticline at the $\mathrm{LCu}$ reflector is $\sim 0.65 \mathrm{~km}$ higher than the Kemik imbricate zone in the footwall to the north. The second area is on the crest and backlimb of the hangingwall anticline of the next basement fault to the south, which appears to flatten upsection around the Kingak to pebble shale interval. Widely spaced imbrication is visible in the backlimb.

The most significant thing about these two anticlines in apparent Kemik is that they lie at least $\sim 0.65 \mathrm{~km}$ below surface exposures of Kemik, which requires significant thrust duplication. The seismic data are too incoherent surrounding the areas of $\mathrm{LCu}$ reflectors to define the structural geometry in detail. However, the distribution of Kemik surface exposures relative to the underlying $\mathrm{LCu}$ reflectors indicates overlap across a distance of $\sim 8$ $\mathrm{km}$. Both the seismic data and surface exposures show significantly less imbrication than in the imbricated zone in the subsurface north of the Shublik Mountains fault, with the possible exception of the exposed zone of faulted folds that extends for $\sim 1.25 \mathrm{~km}$ along the west bank of the Canning River.

Reflectors above the $\mathrm{LCu}$ cannot be reliably correlated with stratigraphic units and traced in the more deformed parts of the lines south of the Kavik fault (sheets 1-3). However, unidentified reflectors define gentle, long-wavelength $(\sim 2-6 \mathrm{~km})$ folds, with local tighter parasitic folds. The most prominent of these is a wide syncline that can be identified on all three lines $\sim 9$ to16 km south of the Kavik fault, from east to west. These folds generally conform to the basement-cored folds lower in the section, but commonly are gentler and locally are out of phase.

\section{CROSS SECTIONS}

The cross sections integrate the surface observations with the interpretations of the seismic reflection data. The cross sections follow the seismic lines along a south trend from the northern edge of the map area to 
the south end of each seismic line. The cross sections continue south to the southern edge of the map area, with a bend to a south-southwest trend so that they are normal to exposed surface structures.

The vertical scale of the interpreted seismic reflection lines is in two-way travel time, so the vertical scale of the interpretations needed to be converted to depth. This was done using seismic velocities compiled from wells in and adjacent to the map area (Foland and Lalla, 1987; Banét, 1992). Unit velocities were combined with unit thicknesses from wells in the map area to determine velocities for the intervals between the interpreted horizons. These interval velocities were then used to calculate depths at key points along each line, and the interpretations were interpolated between these points.

Surface contacts and apparent dips along each line were used to project structure into the subsurface. Surface data from either side of the cross section lines was projected up- or down-plunge as appropriate. Along the seismic lines, structure was projected from the surface only to around the sea-level upper datum of the seismic lines. Surface structure south of the seismic lines was projected to the depth of the seismic interpretation using unit thicknesses determined from the surface mapping combined with an interpretation of the regional structural style based on the seismic interpretations and surface observations outside the map area. South of the mountain front, projection of basement-cored folds and parasitic detachment folds is relatively well constrained by the surface structure, but interpretations in the basement are speculative.

Correlation between the units and structures exposed at the surface south of the mountain front and equivalent units and structures in the seismic lines was challenging for several reasons. The surface structures in Kingak and younger units (fig. 3) north of the mountain front provide a limited basis from which to infer subsurface structures in Shublik and older units because of detachment and structural thickening in Kingak and higher detachments. The gap in data between the mountain front and the southern ends of the seismic lines was expanded by the southward deterioration of seismic data quality.

Stratigraphic thicknesses for units from Kekiktuk through Shublik (fig. 3) were different depending on whether they were determined on the basis of surface exposures or well data. This probably represents a combination of several different causes. These units display facies changes and decrease in depositional thickness to the north. The thicknesses determined from surface exposures are probably greater than original depositional thickness because of an unknown amount of layer-parallel shortening by strain and parasitic folding. Uncertainties in the seismic velocities probably produce some error in the thicknesses interpreted between reflec- tors in the seismic data. The thickness differences were accommodated as realistically as possible in the gaps between surface data and interpretable seismic data.

\section{STRUCTURAL INTERPRETATIONS}

The structure in the map area is significantly influenced by the mechanical stratigraphy (fig. 3). Incompetent detachment intervals separate competent intervals throughout the stratigraphic section. Major detachments are at unknown depth(s) in the basement and in the Kayak, Kingak, and pebble/Hue shales. Basement (with a thin veneer of Kekiktuk) plays a dominant role because it is the lowest and thickest competent unit. Lisburne through Shublik essentially act as a single competent interval, modified by some parasitic folding above minor detachments at the base of Echooka and in Kavik Shale. Although it is relatively thin, the competent Kemik Sandstone is bounded below and above by thick, incompetent intervals and so displays some of the most complex and interesting structures in the area. The Canning Formation is a thick, moderately competent interval that is prone to folding because it consists of relatively thin-bedded sandstone and mudrock. The coarser-grained and thicker-bedded Sagavanirktok Formation tends to form gentler, longer-wavelength folds.

The basement-involved structure visible in the seismic reflection data differs markedly from that in most neighboring parts of the northeastern Brooks Range. Anticlinoria in the northeastern Brooks Range typically have long, gentle backlimbs, steeper forelimbs, and flat crests, and their forelimbs generally are not bounded by faults that cut up from basement. These characteristics suggest that they are fault-bend folds formed beneath a roof thrust in Kayak Shale (fig. 4) (Wallace and Hanks, 1990; Wallace, 1993). In addition, Lisburne is strongly detachment-folded above Kayak. In contrast, the basement faults in the subsurface of the Kavik map area all cut upsection across the Kayak Shale. Lisburne displays little or no detachment folding. These observations suggest that Kayak has not acted as a significant detachment horizon north of the range front.

The Sadlerochit and Shublik Mountains range-front faults (fig. 2) are exceptional in the northeastern Brooks Range because they cut upsection steeply from basement at least to Canning Formation (Meigs, 1989; McMullen, 1989; Wallace and Hanks, 1990; Wallace, 1993). The Sadlerochit Mountains fault apparently continues westward into the subsurface as the Kavik fault, and the eastern seismic line shows a fault apparently equivalent to the Shublik Mountains fault. Both of these faults dip steeply to the south and strike east, in contrast with the east-northeast trend that dominates other structures in the map area. South-dipping pre-Middle Devonian stratigraphy is repeated in the Sadlerochit and Shublik 
Mountains beneath the sub-Mississippian unconformity, which requires southward tilting in each range before Mississippian deposition. This relation is most easily explained if the present range-front faults are reactivated pre-Middle Devonian thrust faults (Wallace and Hanks, 1990; Wallace, 1993). The unusually steep dip and laterally extensive linear trace of the Sadlerochit Mountains-Kavik fault suggests that it may have a strike-slip component, which likely is right-lateral if the dominant east-northeast structural trend reflects north-northwest tectonic transport. The extent to which other basement faults in the map area may be reactivated older faults is unknown.

Backthrusts are present in the subsurface north of the mountain front (sheets 1-3), in contrast with the absence of backthrusts in basement through Shublik in the northeastern Brooks Range (Wallace and Hanks, 1990; Wallace, 1993). The backthrusts generally define the upper surfaces of wedge structures that overlie forethrusts that cut upsection from basement. The stratigraphic position of the wedge tip, where the lower forethrust meets the upper backthrust, varies from deep in basement to the lower part of the Lisburne. It does not appear to be localized on an obvious detachment horizon.

Based on fold and fault geometry, the hangingwall anticlines over the basement faults north of the mountain front do not appear to be fault-bend folds related to abrupt changes in dip of the underlying fault. Instead, they appear to have formed by displacement over gently curved faults and/or by truncation of an existing fold where footwall synclines are visible.

The Lisburne to Shublik interval (fig. 3) displays a general lack of detachment folding and instead behaves as a relatively competent multilayer sequence. Gentle parasitic folds with $\sim 1-2.5 \mathrm{~km}$ wavelengths are locally present in parts of the section. At the base of the interval, these folds appear to originate at the top of the basement rather than being detached in Kayak. This behavior is another contrast of the subsurface north of the mountain front with structure in most adjacent parts of the northeastern Brooks Range, where detachment folds are ubiquitous above a major detachment in Kayak and minor detachments in Sadlerochit. The exception is in the Sadlerochit Mountains, where Kayak is stratigraphically thin to absent. The reason for the lack of subsurface detachment folding is unknown, but may relate to thinning and/or grain-size increase in Kayak.

The structure at the top of basement is relatively well constrained, but the structure in basement is largely unknown because of lack of coherent data. In the cross sections, the geometry of the hangingwall anticlines was used to project the best-defined basement faults down to a gently dipping to flat detachment. The depth to this detachment is inferred to increase from east to west from $\sim 19,000$ to $\sim 24,000 \mathrm{ft}$, but these depths are very uncertain. The cross sections have not been balanced, but the amount of shortening at the top of basement and in Kekiktuk to Shublik (fig. 3) does not appear to be sufficient to account for the structural relief displayed by the top of basement. This apparent discrepancy may be accounted for by some combination of layer-parallel shortening by parasitic folds and strain (cleavage), isostatic uplift as a consequence of erosional unroofing, and/or internal shortening of basement above another deeper detachment, as proposed by O'Sullivan and Wallace (2002).

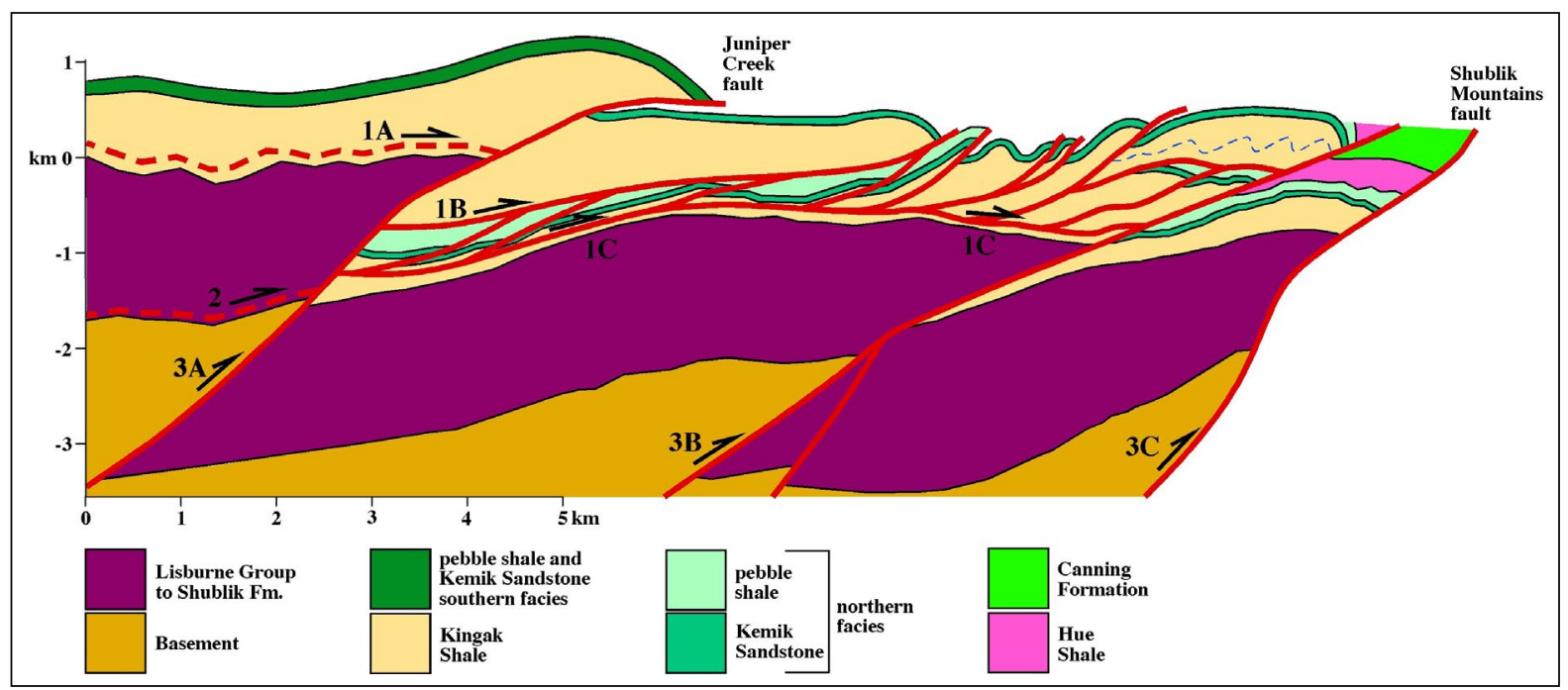

Figure 12. Structural interpretation of middle part of eastern cross section. The surface observations and seismic reflection data together support significant structural duplication of Kemik Sandstone above a detachment in the Kingak Shale. (See text for detailed explanation.) 
Other than the basement-involved structure, the most conspicuous structure in the map area is folding and faulting of Kemik between detachments in the Kingak and pebble shales (fig. 3; sheets 1-3). The imbricate zones visible in the seismic data appear similar to Kemik duplexes observed on the southwest and northeast flanks of the Sadlerochit Mountains (fig. 2) (Meigs, 1989; Rogers, 1992; Wallace and Hanks, 1990; Wallace, 1993). The imbricate zones die out to the north near the Kavik fault, which corresponds with erosional truncation of Kingak and older units beneath the LCu north of the Kavik fault. The duplex may terminate northward because of loss of the Kingak detachment interval and facies changes in Kemik, as observed in the Sadlerochit Mountains and to the south in Ignek Valley (Kelley and Foland, 1987; Mull, 1987). The duplex is replaced southward by folds that are locally broken by more widely spaced faults.

Kingak, Kemik, and pebble shale (fig. 3) also display large-scale thrust duplication south of the duplex on at least the eastern line (sheet 1). This could represent up to $8 \mathrm{~km}$ of thrust overlap, but the seismic data allow other interpretations that require less fault overlap. The eastern cross section shows minimum overlap of $\sim 4.5$ $\mathrm{km}$ on a single thrust to the south, with more local thrust duplication to the north in the area of the exposed broken folds. In summary, Kemik displays different structural styles from south to north including large-scale thrust duplication, broken folds, a duplex, and little or no deformation. The zone of strong structural disruption in the overlying Hue and Canning Formations lies just north of the leading edge of the broken folds.

Deformation of Kemik probably proceeded from south to north, assuming a normal forward-propagating deformation sequence. The faulting of Kemik clearly preceded basement-involved deformation because the Kemik structures are breached in several places by basement-involved thrusts and are folded over basementcored folds as far north as Kavik anticline.

The geometry and timing of these structures are well illustrated around the Juniper Creek fault on the eastern line (sheet 3 and fig. 12). Reflectors that are best interpreted to mark the $\mathrm{LCu}$ and overlying Kemik Sandstone are visible in the seismic data between the Juniper Creek and Shublik Mountains faults. These reflectors underlie extensive exposures of Kemik, thus requiring significant thrust duplication of Kemik. This shortening is accommodated up-section in a zone of strong structural disruption in the Hue Shale and lower Canning Formation (fig. 2).

Stratigraphic, structural, and reflector characteristics define three different packages in this area that I interpret to overlie gently dipping detachments in Kingak Shale at depth. In exposures south of the Juniper Creek fault, the Juniper sandstone, pebble shale unit, and a thin Kemik facies (Kkt; Wartes and others, 2011) overlie structurally thickened Kingak Shale (above 1A, fig. 12). The seismic reflection data are poor this far south, but are most conservatively interpreted to show a stratigraphic section from basement to the top of Shublik that is folded but not duplicated by thrusting (between 1A and 2, fig. 12). North of the Juniper Creek fault, the pebble shale is overlain by Hue Shale instead of Juniper sandstone and the Kemik is the thicker massive facies (Kkm; Wartes and others, 2011). At the surface, but just off the line of section, Kemik is gently folded but not apparently cut by thrust faults for about $4 \mathrm{~km}$ north of the Juniper Creek fault (above 1B, fig. 12), with a belt of faulted folds in Kemik for about $4 \mathrm{~km}$ north of that (sheet 1). Reflectors that appear to define a thin zone of imbricated Kemik (between 1B and 1C, fig. 12) are visible in the seismic data from the exposed faulted Kemik as far south as the Juniper Creek fault. This imbricate zone underlies the gently folded Kemik, thus requiring at least $4 \mathrm{~km}$ of displacement on a thrust sheet that presumably places Kingak over pebble shale. Imbrication of Kemik is visible both at the surface and in the seismic data in the zone of faulted folds in Kemik, thus requiring significant additional thrust duplication in this area within the Kingak, Kemik, and pebble shale interval (sheet 1).

These relations have important implications for the relative timing of structures. Displacement above a detachment in Kingak resulted in structural thickening of Kingak to the south (above 1A, fig. 12), displacement of a sheet of folded Kingak and Kemik north of that (above 1B, fig. 12), and imbrication of Kemik between Kingak and pebble shale in the zone of faulted folds to the north (above 1C, fig. 12). These events most likely occurred in a forward-propagating sequence from south to north, with shortening in the zone of faulted folds accommodated at least in part by structural thickening of Kingak to the south, especially in the vicinity of the future Juniper Creek fault.

Folding to the south between basement and the top of the Shublik Formation likely occurred above a main detachment in Kayak Shale (2, fig. 12) and a subordinate detachment in Kavik Shale, probably during or after detachment in Kingak.

The Juniper Creek fault (3A, fig. 12) is defined by a significant south-side-up offset of the top of basement and of Shublik in the seismic data. It clearly truncates earlier structures above the Kingak detachment (1A-C, fig. 12) and thus is a breaching thrust like many of the other basement-involved thrusts in the Kavik area. The fault corresponds with the boundary between the southern and northern facies in the Cretaceous units, but exposures are too poor and discontinuous to determine the nature or exact location of the facies transition. It is possible that the fault reflects reactivation of a normal fault that influenced Cretaceous deposition. Similar breaching thrusts (3B and 3C, fig. 12) cut upsection from 
basement to the north of Juniper Creek fault.

Previously published fission-track ages provide some insight into the absolute timing of structural events. Fission-track ages in and adjacent to the map area indicate cooling attributed to deformation events at $\sim 45, \sim 35$, and $\sim 27 \mathrm{Ma}$ that formed the northeastern Brooks Range (O'Sullivan and others, 1998; O'Sullivan and Wallace, 2002). Northeastern Brooks Range structures in Mississippian and younger rocks typically trend east-northeast, reflecting tectonic transport to the north-northwest during formation of the northeastern Brooks Range. Farther west, fission-track ages indicate that the central Brooks Range mountain front and the folds in its foothills formed at $\sim 60 \mathrm{Ma}$ (O’Sullivan, 1996; O'Sullivan and others, 1997). Both the mountain front and the foothills folds trend east, reflecting northward tectonic transport during the $\sim 60 \mathrm{Ma}$ deformation. The folds and faults in Kemik display significantly more shortening than does a comparable stratigraphic position to the west in the central Brooks Range foothills, which suggests that the Kemik structures are too far north to have formed during the $\sim 60 \mathrm{Ma}$ deformation. Their uniform east-northeast trend suggests that they formed during the $\sim 45 \mathrm{Ma}$ and younger evolution of the northeastern Brooks Range, perhaps at $\sim 45 \mathrm{Ma}$ since they are among the earliest structures in the relative sequence. Although they are relatively later, the absolute timing of the basementinvolved structures is less clear. The fission-track data in the northeastern Brooks Range suggest that they did not form in a simple forward-propagating sequence, but that significant out-of-sequence deformation took place throughout the evolution of the northeastern Brooks Range (O'Sullivan and others, 1998; O'Sullivan and Wallace, 2002).

\section{SUMMARY AND CONCLUSIONS}

The character of structures changes from south to north in the Kavik River map area. South of the range front, a structural detachment in the Kayak Shale separates first-order fault-bend folds in basement from second-order detachment folds in the overlying Lisburne and Sadlerochit Groups. Thrust faults are rare above the Kayak detachment but third- and higher-order parasitic detachment folds are common above Kayak and subordinate detachments in the Sadlerochit Group.

Kingak Shale is structurally thickened by folds and thrust faults in a wide belt immediately north of the range front. Exposures and seismic data are both poor in this belt, so its subsurface structure is very uncertain.

To the north, seismic data show that faults typically cut upsection from basement, commonly to the surface, and that detachment folds are generally absent in Lisburne and Sadlerochit. Most basement thrusts dip steeply to the south, but local backthrusts cut upsection from basement to varying stratigraphic levels.
Basement thrusts cannot be correlated reliably across the map area except for the Kavik fault, a major east-striking and unusually steeply dipping basementinvolved thrust in the northern part of the map area. This fault and its hangingwall anticline can be traced continuously eastward across the map area into the Sadlerochit Mountains range-front fault and anticline.

The competent Kemik Sandstone displays a variety of closer-spaced folds and thrust faults between detachments in the underlying Kingak Shale and the overlying pebble shale unit. To the south, Kemik is duplicated on low-angle thrust faults with significant displacement. This is succeeded to the north by a zone of broken and imbricated folds exposed at the surface and a subsurface duplex farther north. Detached structures are mostly absent in subsurface Kemik north of the Kavik fault. Kemik detachment preceded basement faulting in the relative structural sequence because basement-involved faults and folds commonly overprint detached structures in Kemik.

Long-wavelength folds north of the range front conform to first-order basement folds at least up to the pebble shale detachment, but are locally disharmonic above that detachment. A strongly disrupted zone of complex folds and faults that is exposed in Hue Shale and Canning Formation appears to correspond with the north edge of the broken and imbricated Kemik folds. Gentle, long-wavelength folds dominate in the Canning and Sagavanirktok Formations to the north, but local tighter parasitic folds in Canning are locally exposed or visible in seismic data.

The east-northeast trend or strike of most traceable folds and faults is consistent with tectonic transport to the north-northwest during Eocene and younger formation of the northeastern Brooks Range. However, the eaststriking Sadlerochit Mountains range-front fault can be traced westward into the map area as the Kavik fault, and the similar Shublik Mountains range-front fault can be traced into the eastern part of the map area. Their east strike probably reflects reactivation of pre-existing basement thrust faults. The strike and unusually steep dip of these faults suggest that they may have had a right-lateral strike-slip component during their reactivation.

\section{ACKNOWLEDGMENTS}

Geologic mapping for this area was supported in part by the National Cooperative Geologic Mapping Program's STATEMAP program under award number 06HQAG0024, administered by the U.S. Geological Survey. Additional funding was provided through State of Alaska Capital Improvement Project funds. Additional support for field studies was provided by a consortium of sponsors including Conoco Phillips, Anadarko, ENI, Petro-Canada, BG Alaska, FEX, Pioneer Natural Resources, and Shell. 
Subsurface interpretation was made possible thanks to seismic reflection data provided by BP and ARCO, and made available through the U.S. Geological Survey National Archive of Marine Seismic Surveys (NAMSS). For further information please visit: http://walrus. wr.usgs.gov/NAMSS/. These data are part of the North Slope (W-40-80-AK) survey. Paul Decker (Alaska Division of Oil and Gas) identified the unit tops at well locations in the seismic data by correcting log data for two-way travel time.

These interpretations of seismic reflection data and structural cross sections for the Kavik River map area benefited from thorough reviews by David W. Houseknecht (U.S. Geological Survey) and Thomas X. Homza (Shell Exploration \& Production Company).

\section{REFERENCES CITED}

Anderson, A.V., Wallace, W.K., and Mull, C.G., 1994, Depositional record of a major tectonic transition in northern Alaska; Middle Devonian to Mississippian rift-basin margin deposits, upper Kongakut River region, eastern Brooks Range, Alaska, in Thurston, D., and Fujita, K., eds., 1992 Proceedings International Conference on Arctic Margins, U.S. Minerals Management Service Outer Continental Shelf Study 94-0040, p. 71-76.

Bader, J.W., and Bird, K.J., 1986, Geologic map of the Demarcation Point, Mount Michelson, Flaxman Island, and Barter Island quadrangles, Alaska: U.S. Geological Survey Miscellaneous Investigations Map I-1791, 1 sheet, scale 1:250,000.

Banét, A.C., Jr., 1992, Log analysis of Aurora 890-\#1 OCS-Y-0943 well, offshore of the Arctic National Wildlife Refuge 1002 area, northeast Alaska: BLMAlaska Technical Report 15, 37 p.

Foland, R.L., and Lalla, D.J., 1987, Seismic-reflection data acquisition, processing, and interpretation, in Bird, K.J., and Magoon, L.B., eds., Petroleum geology of the northern part of the Arctic National Wildlife Refuge, northeastern Alaska: U.S. Geological Survey Bulletin 1778, p. 235-243.

Kelley, J.S., and Foland, R.L., 1987, Structural style and framework geology of the coastal plain and adjacent Brooks Range, in Bird, K.J., and Magoon, L.B., eds., Petroleum geology of the northern part of the Arctic National Wildlife Refuge, northeastern Alaska: U.S. Geological Survey Bulletin 1778, p. 255-270.

Loveland, A.M., 2010, Fracture evolution in a fold-andthrust belt and the adjacent foreland basin; An example from the northeastern Brooks Range, Alaska: Fairbanks, University of Alaska, M.S. Thesis, 167 p.

McMullen, B.S., 1989, Structural geometry and evolution of the western Shublik Mountains, northeastern
Brooks Range, Alaska: Fairbanks, University of Alaska, M.S. Thesis, $171 \mathrm{p}$.

Meigs, A.J., 1989, Structural geometry and sequence in the eastern Sadlerochit Mountains, northeastern Brooks Range, Alaska: Fairbanks, University of Alaska, M.S. Thesis, $220 \mathrm{p}$.

Moore, T.E., Wallace, W.K., Bird, K.J., Karl, S.M., Mull, C.G., and Dillon, J.T., 1994, Geology of northern Alaska, in Plafker, George, and Berg, H.C., The Geology of Alaska: Geological Society of America, v. G-1, p. 49-138.

Mull, C.G., 1987, Kemik Sandstone, Arctic National Wildlife Refuge, northeastern Alaska, in Tailleur, I.L., and Weimer, P., eds., Alaskan North Slope geology: Pacific Section SEPM and Alaska Geological Society, book 50, p. 405-431.

O'Sullivan, P.B., 1996, Late Mesozoic and Cenozoic thermal-tectonic evolution of the North Slope foreland basin, Alaska, in Johnsson, M.J., and Howell, D.G., eds., Thermal evolution of sedimentary basins in Alaska: U.S. Geological Survey Bulletin 2142, p. 45-79.

O'Sullivan, P.B., and Wallace, W.K., 2002, Out-of-sequence, basement-involved structures in the Sadlerochit Mountains region of the Arctic National Wildlife Refuge, Alaska; Evidence and implications from fission-track thermochronology: Geological Society of America Bulletin, v. 114, no. 11, p. 1,356-1,378.

O'Sullivan, P.B., Murphy, J.M., and Blythe, A.E., 1997, Late Mesozoic and Cenozoic thermotectonic evolution of the central Brooks Range and adjacent North Slope foreland basin, Alaska, including fission track results from the Trans-Alaska Crustal Transect (TACT): Journal of Geophysical Research, v. 102, p. 20,821-20,845.

O'Sullivan, P.B., Wallace, W.K., and Murphy, J.M., 1998, Fission-track evidence for apparent out-ofsequence Cenozoic deformation along the Philip Smith Mountain front, northeastern Brooks Range, Alaska: Earth and Planetary Science Letters, v. 164, no. 3-4, p. 435-449.

Potter, C.J., Perry, W.J., Grow, J.A., and Lee, M.W., 1999, Style and timing of thrust-faulting in the 1002 area, Arctic National Wildlife Refuge, in ANWR Assessment Team, Oil and gas resource potential of the 1002 area, Arctic National Wildlife Refuge, Alaska: U.S. Geological Survey Open-File Report 98-34, CD-ROM, p. BD 1-32.

Potter, C.J., Grow, J.A., Perry, W.J., Moore, T.E., O'Sullivan, P.B., Phillips, J.D., and Saltus, R.W., 2004, Tertiary thrust systems and fluid flow beneath the Beaufort coastal plain (1002 area), Arctic National Wildlife Refuge, Alaska, U.S.A., in Swennen, 
Rudy, Roure, Francois, and Granath, J.W., eds., Deformation, fluid flow, and reservoir appraisal in foreland fold and thrust belts: American Association of Petroleum Geologists Hedberg series, no. 1, p.

Reifenstuhl, R.R., Mull, C.G., Harris, E.E., LePain, D.L., Pinney, D.S., and Wallace, W.K., 2000, Geologic map of the Sagavanirktok B-1 Quadrangle, eastern North Slope, Alaska: Alaska Division of Geological \& Geophysical Surveys Report of Investigations 2000-1A, 15 p., 1 sheet, scale 1:63,360.

Reiser, H.N., Brosgé, W.P., Dutro, J.T., Jr., and Detterman, R.L., 1971, Preliminary geologic map, Mount Michelson Quadrangle, Alaska: U.S. Geological Survey Open-File Report 71-237, 2 sheets, scale $1: 200,000$.

Robinson, M.S., Decker, J.E., Clough, J.G., Reifenstuhl, R.R., Bakke, Arne, Dillon, J.T., Combellick, R.A., and Rawlinson, S.A., 1989, Geology of the Sadlerochit and Shublik Mountains, Arctic National Wildlife Refuge, northeastern Alaska: Alaska Division of Geological \& Geophysical Surveys Professional Report 100, scale 1:63,360, 1 sheet.

Rogers, J.A., 1992, Lateral variation of range-front structures and structural evolution of the central Shublik Mountains and Ignek Valley, northeastern Brooks Range, Alaska: Fairbanks, University of Alaska, M.S. Thesis, 128 p.
Wallace, W.K., 1993, Detachment folds and a passiveroof duplex: Examples from the northeastern Brooks Range, Alaska, in Solie, D.N., and Tannian, Fran, eds., Short notes on Alaskan geology 1993: Alaska Division of Geological \& Geophysical Surveys Geologic Report 113, p. 81-99.

Wallace, W.K., and Hanks, C.L., 1990, Structural provinces of the northeastern Brooks Range, Arctic National Wildlife Refuge, Alaska: American Association of Petroleum Geologists Bulletin, v. 74, p. 1,100-1,118.

Wallace, W.K., Moore, T.E., and Plafker, George, 1997, Multistory duplexes with forward dipping roofs, north-central Brooks Range, Alaska: Journal of Geophysical Research, v. 102, no. B9, p. 20,773-20,796.

Wartes, M.A., Wallace, W.K., Loveland, A.M., Gillis, R.J., Decker, P.L., Reifenstuhl, R.R., Delaney, P.R., LePain, D.L., and Carson, E.C., 2011, Geologic map of the Kavik River area, Mount Michelson Quadrangle, Alaska: Alaska Division of Geological \& Geophysical Surveys Report of Investigation 2011-3A, 15 p., 1 sheet, scale 1:63,360. 


\section{APPENDIX}

\section{Abbreviations for unit tops and other well markers on Kavik area seismic lines}

$\begin{array}{ll}\text { PFROST } & \text { permafrost } \\ \text { MTTkc } & \text { Mikkelsen Tongue of Canning Formation } \\ \text { STTs } & \text { Staines Tongue of Sagavanirktok Formation } \\ \text { K-15 } & \text { K-15 log marker } \\ \text { SCBF } & \text { Schrader Bluff Formation } \\ \text { TKc3 } & \text { Canning Formation, interval 3 } \\ \text { UTTs } & \text { unnamed tongue of Sagavanirktok Formation } \\ \text { TKc2 } & \text { Canning Formation, interval 2 } \\ \text { LUTTs } & \text { lower unnamed tongue of Sagavanirktok Formation } \\ \text { TKc1 } & \text { Canning Formation, interval 1 } \\ \text { Maas-Camp } & \text { Maastrichtian-Campanian } \\ \text { MCu } & \text { Mid-Cretaceous unconformity } \\ \text { Kh } & \text { Hue Shale } \\ \text { HRZ } & \text { highly radioactive zone } \\ \text { Kps } & \text { pebble shale unit } \\ \text { Kk } & \text { Kemik Sandstone } \\ \text { LCu } & \text { Lower Cretaceous unconformity } \\ \text { KJk } & \text { Kingak Shale } \\ \text { Trsr } & \text { Sag River Formation } \\ \text { Trs } & \text { Shublik Formation } \\ \text { Trfc } & \text { Fire Creek Siltstone Member of Ivishak Formation } \\ \text { Trl } & \text { Ledge Sandstone Member of Ivishak Formation } \\ \text { Trk } & \text { Kavik Shale Member of Ivishak Formation } \\ \text { Pe } & \text { Echooka Formation } \\ \text { PMl } & \text { Lisburne Group } \\ \text { PMlu } & \text { Wahoo Limestone of Lisburne Group } \\ \text { PMll } & \text { Alapah Limestone of Lisburne Group } \\ \text { Mky } & \text { Kayak Shale } \\ \text { Mkt } & \text { Kekiktuk Conglomerate } \\ \text { pM } & \text { pre-Mississippian } \\ & \end{array}$

